\title{
Unreported Abnormality of Hepatobiliary System in Trisomy 13: Choledochal Cyst
}

\section{Trizomi 13’te Bildirilmemiş Bir Hepatobilier Sistem Anomalisi: Koledok Kisti}

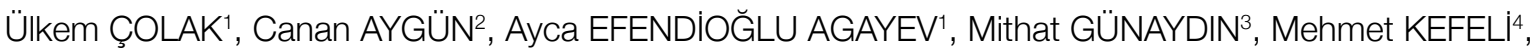 \\ Fatma Zeynep ÖZEN ${ }^{4}$
}

\author{
${ }^{1}$ Ondokuz Mayıs University, Faculty of Medicine, Department of Child Health and Diseases, Samsun, Turkey \\ 2Ondokuz Mayıs University, Faculty of Medicine, Department of Child Health and Diseases, Neonatal Department, Samsun, Turkey \\ ${ }^{3}$ Pediatric Surgery Specialist, Samsun, Turkey \\ ${ }^{4}$ Ondokuz Mayıs University, Faculty of Medicine, Department of Pathology, Samsun, Turkey
}

\begin{abstract}
Trisomy 13 is the third most common autosomal trisomy after trisomy 21 and 18. It is associated with malformations of genitourinary, gastrointestinal and central nervous system. Despite these broad range of malformations, there are few case reports regarding hepatobiliary system abnormalities. Choledochal cyst in association with trisomy 13 had not been reported yet. In this paper we aimed to present a case of trisomy 13, who had signs of intestinal obstruction and cholestasis and was diagnosed as choledochal cyst eventually. We conclude clinicans could consider choledochal cyst in cases of trisomy 13, presenting with gastrointestinal system obstruction.
\end{abstract}

Key Words: Choledochal cyst,Trisomy 13

\section{ÖZET}

Trizomi 13; Trizomi 21 ve 18'den sonra en sık görülen üçüncü otozomal trizomi olup kardiyak, genitoüriner, gastrointestinal ve santral sinir sistemini de içeren birçok malformasyona neden olur. Tanımlanmış ve iyi bilinen birçok malfosmasyona rağmen, trizomi 13'te yayınlanmış hepatobiliyer malformasyon nadirdir. Koledok kistine eşlik eden trizomi 13 ise daha önce bildirilmemiştir. Bu yazıda intestinal obstruksiyon ve kolestaz bulguları olan ve sonuç olarak koledok kisti tanısı alan bir trizomi 13 olgusunu sunmayı hedefledik. Klinisyenlerin benzer semptomlar gelişen trizomi 13 olgularında koledok kistini de ayırıcı tanıda düşünmeleri vurgulamak istenmiştir.

Anahtar Sözcükler: Koledok kisti, Trizomi 13

\section{INTRODUCTION}

Trisomy 13, first described by Patau in 1960 is the third most common autosomal trisomy with a prevalence of 1.57/10.000 pregnancies (including live births, stillbirths, elective terminations). Although associated malformations of central nervous system, cardiac and genitourinary system have been reported, choledochal cyst had not been reported yet. In this paper, we present a case of trisomy 13 with an unusual abdominal finding in newborn; choledochal cyst. To the best of our knowledge, this is the first case reported that is related to the choledochal cyst in a case with trisomy 13.

\section{CASE REPORT}

The girl baby was the second child of both 30 years old, unrelated parents. She was born at term via cesarean section, weighing $3840 \mathrm{~g}$ (10-25p), length $51 \mathrm{~cm}$ (50-75p) and head circumference of $36 \mathrm{~cm}$ (75-90p). Since fetal ultrasonography performed at $33^{\text {rd }}$ gestational week had shown multiple congenital anomalies (cerebellar vermis hypoplasia, cleft lip and palate, bilateral polydactyly of hands and feet), chromosomal abnormality was suspected. Due advanced gestational age; termination option was not possible. No hepato-billiary abnormality was detected by fetal ultrasound. Postnatally, the baby demonstrated typical abnormalities for trisomy 13 , including aplasia cutis of scalp, capillary hemangiomas at neck, cleft lift and palate, bilateral postaxial polydactyly of hands and feet, 
flexion contractures at hands, arthrogryposis at left hand and bilateral pes echinovarus. She was admitted to Neonatal Intensive Care Unit (NICU) and screened for additional malformations. Magnetic Resonance Imaging (MRI) of the brain showed cerebellar vermis hypoplasia. Transthoracic echocardiography showed bicuspid aorta, patent foramen ovale and mitral insufficiency. Abdominal ultrasound performed on second day of life showed bilateral grade I hydronephrosis. Peripheral chromosomal analysis displayed trisomy 13 (Robertsonian type).

At postnatal 9th day, she started to vomit, feeding intoleranceand fever developed. No acholic stool was observed. Total leukocyte count was $41.760 \mathrm{u} / \mathrm{L}$, hemoglobin $12.8 \mathrm{~g} / \mathrm{dl}$, neutrophil 35140 $\mathrm{u} / \mathrm{l}$, platelet $77000 \mathrm{u} / \mathrm{L}$. C- reactive protein level was $214 \mathrm{mg} /$ dl $(\mathrm{N}:<10 \mathrm{mg} / \mathrm{dl})$. Liver enzymes were elevated and bilirubin levels suggested cholestasis. (AST: 265, ALT: 246, GGT:771 U/L, total bilirubin: $4.5 \mathrm{mg} / \mathrm{dl}$, direct bilirubin: $1.1 \mathrm{mg} / \mathrm{dl}$ ). She was put on nasogastric decompression, nil per os and total parenteral nutrition was started. On the following day, the baby had abdominal distention and fecaloid vomiting was observed. A plain abdominal radiograph suggested intestinal obstruction, (Figure 1) so abdominal exploration was performed. Due to the urgency of situation, MRI scan for abdomen couldn't be performed. Surgical exploration showed, two 4x5 cm cysts near the liver. The cysts were dissected from the peripheral tissue. One of the cysts was gall bladder and the other was type II choledochal cyst; confirmed by histopathological examination. (Figures 2, 3) The cyst was compressing the duodenum, containing bile and was adhered to the gall blader; therefore,

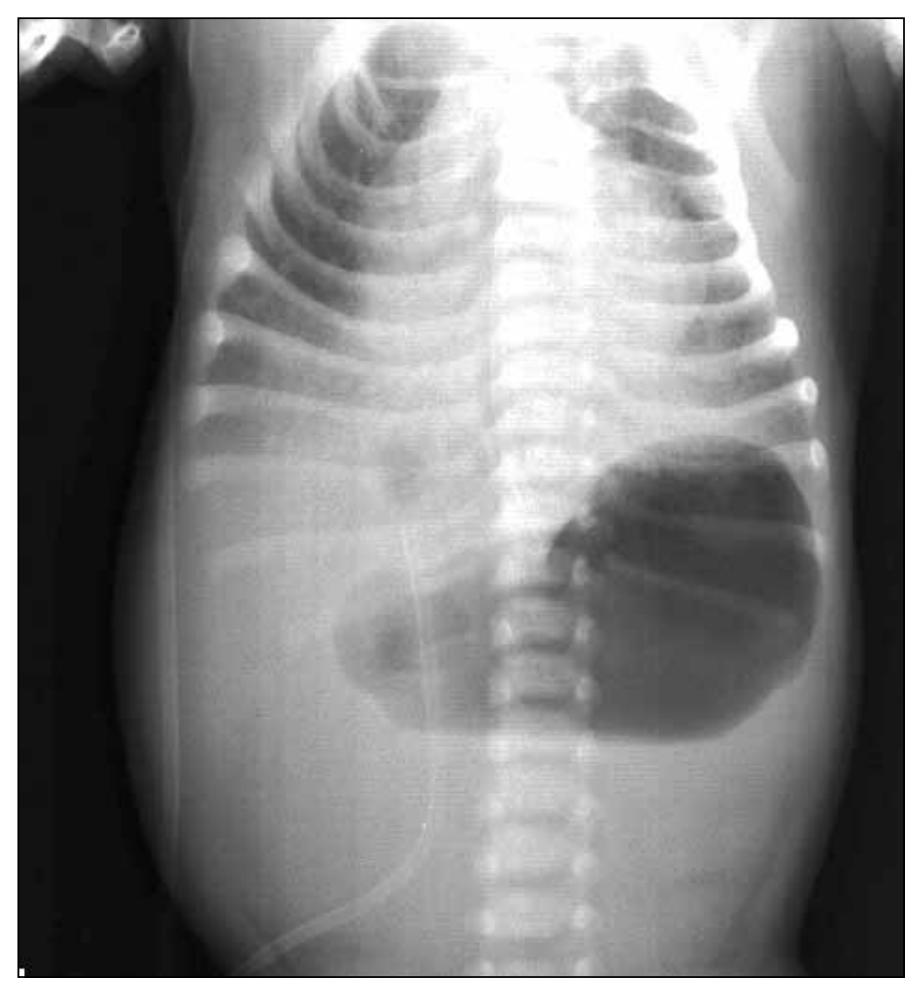

Figure 1: Supine radiograph of abdomen shows a dilated stomach and proximal duodenum. cystectomy and cholecystectomy were performed. After the operation the baby got better on the following days and was extubated on the postoperative second day. Because of nosocomial sepsis and feeding problems, she was discharged when 51 days old.

\section{DISCUSSION}

There are many abnormalities that are associated with trisomy 13: Microcephaly, microophtalmia, iris coloboma, retinal dysplasia, arrhinencephay, cleft lip and/or palate, meningomyelocele, agenesis of corpus callosum, cerebellar hypoplasia, omphalocele, cardiac defects, polycystic kidneys, hydroureterenephrosis, horseshoe kidney, abnormal scrotum, cryptorchidism and bicornuate uterus (2). Gastrointestinal malformations that are

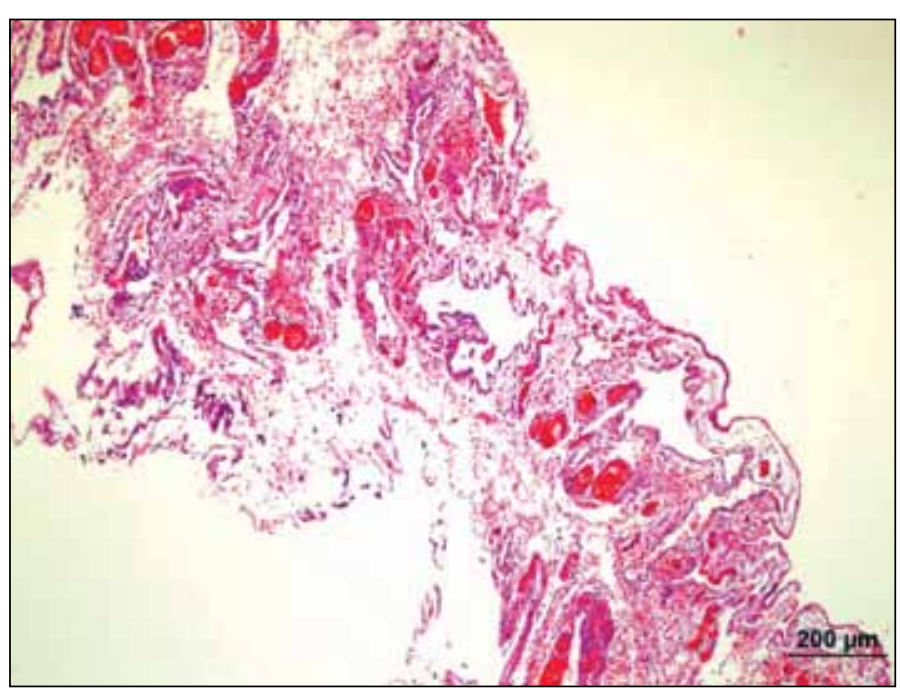

Figure 2: The surface epithelium-free the fibrous cyst wall, numerous congestion vascular structures are observed.

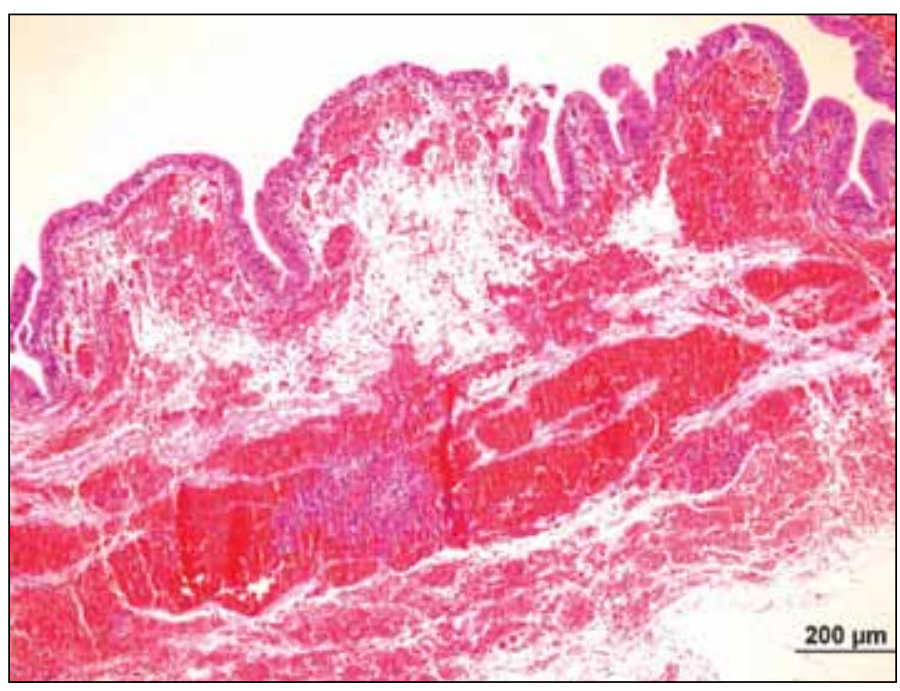

Figure 3: Surface lined by columnar epithelium of the gallbladder wall, almost completely fresh bleeding was observed under the epithelium. 
reported to occur in trisomy 13 are esophageal, tracheoesophageal malformations; abdominal wall defects, Meckel diverticulum and anorectal malformations (3). Single umblical artery, omphalocele, echogenic bowel, bladder extrophy are abnormal abdominal ultrasound findings of trisomy 13 diagnosed prenatally (4). Albeit, malformations of the hepatobiliary tree with trisomy 13 are scarce in the literature. Kara et al reported a baby with trisomy 13 presenting with cholestasis, and eventually diagnosed with absence of gallbladder (5). Sepulveda et al. (6) screened eight fetuses with enlarged galbladder. Prenatal and neonatal caryotype was abnormal in three of them and they were diagnosed as Trisomy 13, 18 and 21. Cheng et al. (7) reported 19 cases of choledochal cyst diagnosed before one years of age in one instution during 17 years and they stated that only one patient had chromosomal abnormality; which was trisomy 18.

Our baby had signs and symptoms of intestinal obstruction and cholestatic jaundice caused by an enlarged choledochal cyst. This case was reported to notice that in patients with Trisomy 13, choledochal cyst should be considered in the differential diagnosis of such symptomatology.

\section{REFERENCES}

1. Crider KS, Olney RS, Cragan JD. Trisomies 13 and 18: Population prevalences, characteristics, and prenatal diagnosis, metropolitan Atlanta, 1994-2003. Am J Med Genet 2008;146:820-6.

2. Matthews AL. Chromosomal abnormalities: Trisomy 18, trisomy 13, deletions, and microdeletions. J Perinat Neonatal Nurs 1999;1:5975.

3. National Organization for Rare Disorders (NORD). Trisomy 13 syndrome.https://rarediseases.org/rare-diseases/trisomy-13-syndrome. 2015.

4. Lehman CD, Nyberg DA, Winter TC 3rd, Kapur RP, Resta RG, Luthy DA. Trisomy 13 syndrome: Prenatal US findings in a review of 33 cases. Radiology 1995;94:217-22.

5. Kara M, Tekedereli I, Durukan M, Bozgeyik Z, Aygun D. Trisomy 13 with the absence of gallbladder. Pediatr Neonatol 2013;54:3489.

6. Sepulveda W, Nicolaidis P, Hollingsworth J, Fisk NM. Fetal cholecystomegaly: A prenatal marker of aneuploidy. Prenat Diagn 1995;15:193-7.

7. Cheng MT, Chang MH, Hsu HY, Ni YH, Lai HS, Chen CC, et al. Choledochal cyst in infancy: A follow-up study. Acta Paediatr Taiwan 2000;41:13-7. 